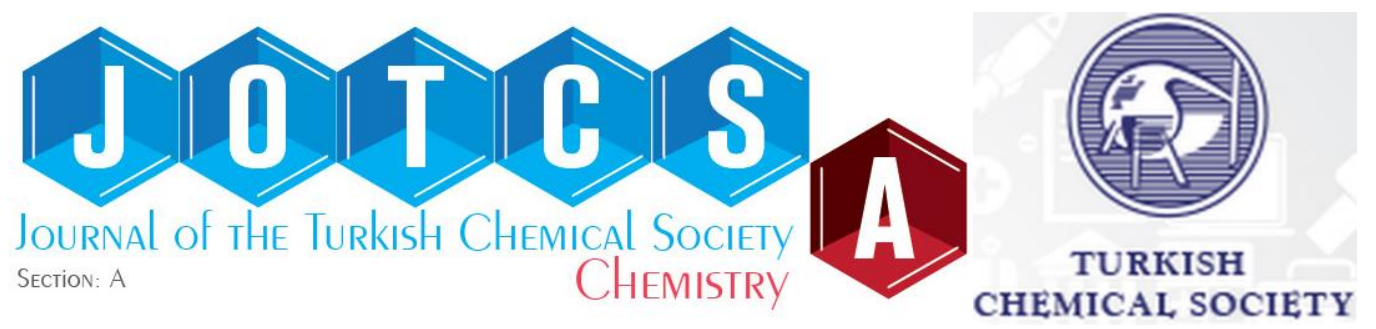

\title{
Optimization of synthetic route to PNA-T-OH monomers
}

\section{Onur Alptürk ${ }^{*}$, $\triangle D$, Aytül Saylam² ${ }^{2}$, Salih Özçubukcu ${ }^{2} D$.}

${ }^{1}$ Istanbul Technical University, Department of Chemistry, 34469, Istanbul, Turkey
${ }^{2}$ Middle East Technical University, Department of Chemistry, 06531, Ankara, Turkey

Abstract: Peptide nucleic acids are synthetic molecules crafted to mimic natural nucleic acids, and thus, they are widely utilized in many chemical, and, biomedical applications. Although there exist many approaches to synthesize monomers to date, there is still room to improve these methodologies. With this motivation, we compared some widely utilized synthetic routes to obtain $N$-Boc-PNA-T-OH, and N-Fmoc-PNA-T-OH. Our results indicate that $N$-Bocethylenediamine is the most pivotal intermediate in the chemistry of PNA, and synthetic route commencing with this material affords these two PNA monomers in relatively high yield, and purity, while being very reproducible.

Keywords: Peptide nucleic acid, monomer synthesis, optimization.

Submitted: January 17, 2018. Accepted: February 26, 2018.

Cite this: Alptürk $\mathrm{O}$ et al., Optimization of synthetic route to PNA-T-OH monomers. JOTCSA. $2018 ; 5(2): 457-468$.

DOI: http://dx.doi.org/10.18596/jotcsa.380410.

*Corresponding author. E-mail: onur.alpturk@itu.edu.tr, Tel: +90(212) 2853249 


\section{INTRODUCTION}

First reported in 1991, peptide nucleic acids (PNA, for short) are single-stranded molecules designed to recognize nucleic acids in sequence-selective manner. By design, these synthetic compounds are composed of $\mathrm{N}$-(2-aminoethyl) glycine moiety harboring a nucleobase in such a way that intact PNA monomer corresponds to an entire nucleoside of natural nucleic acids. Notwithstanding its being inspired from nature, PNA strands indeed diverges structurally from DNA, and RNA; its backbone is constructed through conventional peptide bonds amongst building blocks, in lieu of phosphodiester bonds encountered in nucleic acids (1) (Scheme 1). Unsurprisingly, absence of phosphate group grants a neutral charge to PNA structure and more remarkably, it accounts for superior hybridization propensity of these synthetic oligomers whereby eliminating infamous electrostatic interactions amongst DNA or RNA chains (2). In short, these synthetic oligomers presently emerge as an ideal tool to probe natural nucleic acids and thus, they are extensively utilized in biomedical applications including (but not limited to) antigene and antisense therapies (3), microarrays (4), biosensors (5), and fluorescent in situ hybridization (FISH) assays (6).

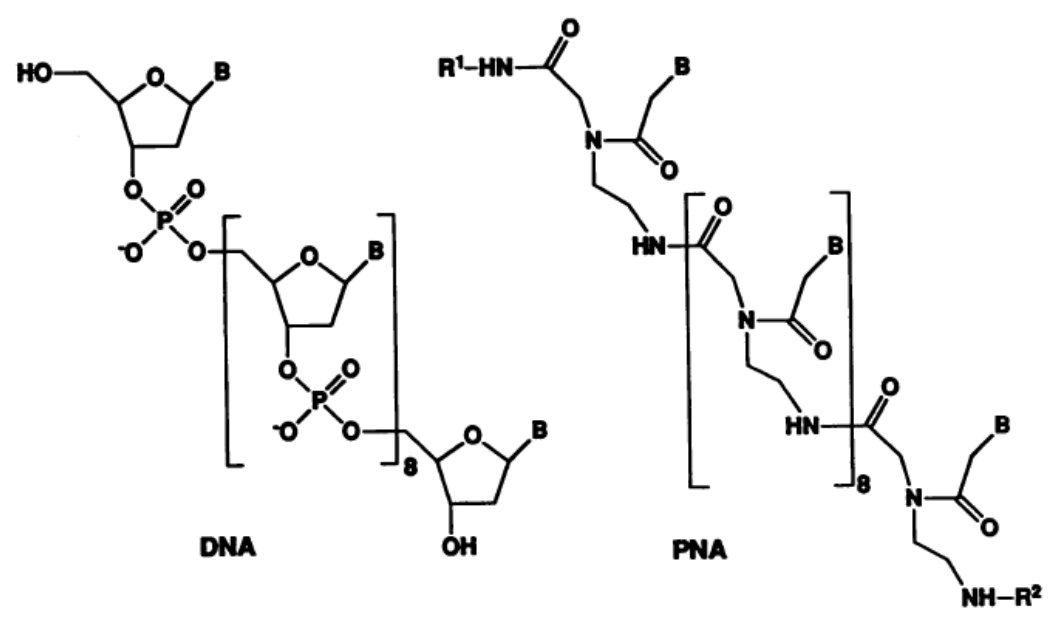

Scheme 1. Structures of DNA and PNA (adapted from reference 1 with permission).

Retro-synthetically, all customary synthetic routes to PNA monomer (1) rely on the coupling of $\mathrm{N}$-(2-aminoethyl) glycine backbone (3) with nucleobase-acetic acid moiety (2 where $\mathrm{B}=$ adenine, cytosine, guanine, or thymine) (Scheme 2). Undoubtedly, this reaction demands protecting groups on both $\mathrm{N}$-terminal (such as Fmoc, Boc and so on), and C-terminal (such as ethyl or tertiary-butyl group and so on) of backbone prior to conjugation of nucleobase harboring moiety. Whereas some routes utilize the coupling of glycine or its derivatives to an electrophile (see routes A-C in Scheme 2) to prepare the backbone (7-9), the others switch the position of the nucleophile whereupon ethylene diamine or its derivatives attack to a glycine-derived electrophile (see routes D, and E in Scheme 2) (10). 

A
$P G_{-} \underset{H}{N} \sim=0+\mathrm{HCl}_{2} \mathrm{H}_{2} \mathrm{~N} \smile \mathrm{COOR}$
B $\mathrm{GP}_{-\mathrm{NH}} \underset{\mathrm{OH}}{ }+$
C $\mathrm{PG}_{\mathrm{H}}^{\mathrm{N}} \sim \mathrm{X}+$
NBS
$\mathrm{H}^{-\mathrm{NBS}} \underset{\mathrm{N}}{\mathrm{N}} \mathrm{COOR}$
$\mathrm{PG}_{\mathrm{H}} \underset{\mathrm{H}}{\sim \mathrm{NH}_{2}+}$
$\mathrm{Br} \sim \mathrm{COOR}$
E $\mathrm{H}_{2} \mathrm{~N} \frown \mathrm{NH}_{2}+$
$\mathrm{Cl} \sim \mathrm{COOH}$

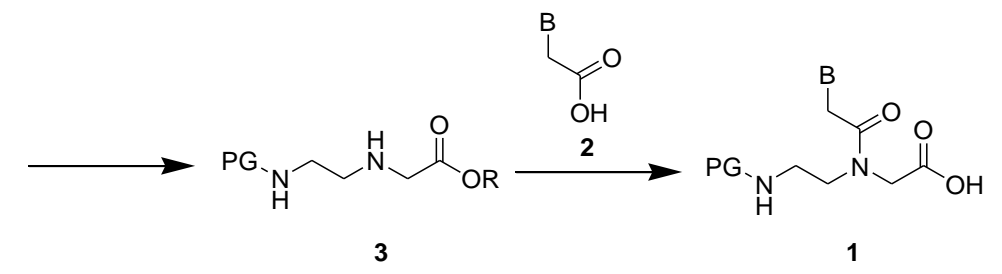

Scheme 2. A summary of synthetic routes to N-protected PNA monomer 1 (PG, and NBS stand for protecting group, and 2-nitrobenzenesulfonyl moiety, respectively).

As effortless as it may seem on paper, the synthesis of PNA backbone could in reality be troublesome, which obliged the scientific community to devise a diverse repertoire of synthetic methodologies. Of them, a small fraction, such as the coupling of chloroacetic acid and ethylenediamine (as in route $E$ ), suffer from poor reproducibility (11). Yet, the chief complication regarding the synthesis of monomers revolves around the observation of how some key reactions (like coupling of nucleobases to the PNA backbone) afford moderate yields, which ultimately demands a chromatographic purification with highly polar solvents $(12,13)$. Naturally, this complication appears tolerable to some extent but it becomes labor-demanding, especially in large scale synthesis where the yields of reactions and difficulties in purification becomes a major concern. As we experienced similar problems in an attempt to synthesize $N$ Boc-PNA-T-OH, and N-Fmoc-PNA-T-OH, we felt compelled to optimize synthetic route leading to these monomers, in conjunction with purification procedures. With this motivation, we have crafted this manuscript to provide a concise comparison of certain methodologies, and key reactions to better the synthesis of these monomers.

\section{MATERIALS AND METHODS}

Ethyl acetate, hexanes, dichloromethane (DCM), tetrahydrofuran (THF), and acetonitrile were purchased from Merck, and were used without any purification. Anhydrous $N, N-$ dimethylformamide (DMF), trifluoroacetic acid (TFA), triisopropylsilane (TIPS), and N-Bocethanol amine were purchased from Sigma-Aldrich. $N, N$-diisopropylethyl amine (DIPEA), ethyl bromoacetate, O-(1H-benzotriazol-1-yl)- $N, N, N^{\prime}, N^{\prime}$-tetramethyl uronium (HBTU), and 12molybdophosphoric acid were purchased from Alfa Aesar. Lithium hydroxide, 9fluorenylmethyl- $N$-succinimidyl carbonate (Fmoc-OSu), and $N$-Boc-ethylenediamine were obtained from EMD Milliopore, ChemImpex, and Ench Industry Co. (Shangai, China), 
respectively. TLC was performed on analytical Merck silica plates with F254 indicator. TLCs were viewed either under $254 \mathrm{~nm}$ UV or by staining with ninhydrin, where indicated.

${ }^{1} \mathrm{H}$ NMR and ${ }^{13} \mathrm{C}$ NMR were acquired on an Agilent VNMRS Spectrometer at $500 \mathrm{MHz}$, and 125 $\mathrm{MHz}$, respectively. Coupling constant values were given in Hertz and chemical shifts were reported in $\delta(\mathrm{ppm})$ with respect to the internal standard TMS. Splitting patterns were described as follows: s (singlet), $d$ (doublet), t (triplet), q (quartet), m (multiplet), and br (broad signal).

\section{EXPERIMENTAL SECTION}

Methyl glycinate hydrochloride 4 (14): To a suspension of glycine $(3.67 \mathrm{~g}, 48.99 \mathrm{mmol})$ in methanol $(100 \mathrm{~mL})$ chilled with an ice bath, $\mathrm{SOCl}_{2}(10.7 \mathrm{~mL})$ was added dropwise over 15 minutes. Then, the ice-bath was removed and the reaction was refluxed for three hours. Excess of thionyl chloride and methanol were evaporated and the product was obtained as white powder (yield 85\%). ${ }^{1} \mathrm{H}$ NMR (DMSO- $\left.\mathrm{d}_{6}\right): 3.7(3 \mathrm{H}, \mathrm{s}) ; 3.85(2 \mathrm{H}, \mathrm{s}), 8.7(2 \mathrm{H}, \mathrm{s}) .{ }^{13} \mathrm{C}$ NMR $\left(\right.$ DMSO-d $\left.\mathrm{d}_{6}\right)$ : 52.9, 168.2.

Methyl $N$-(2-nitrophenylsulfonyl)-glycinate ( $N$-(NBS-Gly-OMe)) 5 (15): Triethyl amine (2.32 $\mathrm{mL}, 16.71 \mathrm{mmol}$ ) and methyl glycinate hydrochloride $(1 \mathrm{~g}, 7.96 \mathrm{mmol})$ were dissolved in dichloromethane $(20 \mathrm{~mL})$ at $0{ }^{\circ} \mathrm{C}$. 2-nitrophenylsulfonyl chloride $(1.94 \mathrm{~g}, 8.75 \mathrm{mmol})$ dissolved in dichloromethane $(15 \mathrm{~mL})$ was added dropwise over 30 minutes. Upon the completion of addition, ice bath was removed and the reaction mixture is further stirred overnight at room temperature. Dichloromethane was evaporated under reduced pressure and the crude material was portioned between ethyl acetate $(50 \mathrm{~mL})$, and distilled water $(60 \mathrm{~mL})$. The organic phase was separated and washed with distilled water $(1 \times 25 \mathrm{~mL}), 1 \mathrm{M} \mathrm{HCl}(2 \times 25 \mathrm{~mL})$, brine $(2 \times 25$ $\mathrm{mL}), 5 \% \mathrm{NaHCO}_{3}(2 \times 25 \mathrm{~mL})$, and brine $(2 \times 25 \mathrm{~mL})$, respectively. Organic phase was dried over $\mathrm{Na}_{2} \mathrm{SO}_{4}$ and concentrated under reduced pressure and the title compound was obtained as white solid (yield 60\%). ${ }^{1} \mathrm{H}$ NMR $\left(\mathrm{CDCl}_{3}\right): 3.64(3 \mathrm{H}, \mathrm{s}), 4.05(2 \mathrm{H}, \mathrm{d}, \mathrm{J}=5 \mathrm{~Hz}) ; 6.16(1 \mathrm{H}, \mathrm{t}, \mathrm{J}=$ $5 \mathrm{~Hz}), 7.67-8.35(4 \mathrm{H}, \mathrm{m}) .{ }^{13} \mathrm{C}$ NMR $(125 \mathrm{MHz}): 44.7,52.5,125.6,130.6,132.9,133.7,133.9$, $147.7,169$.

2-(Boc-amino) ethyl mesylate 6 (16): Tert-butyl (2-hydroxyethyl) carbamate $(1.34 \mathrm{~g}, 8.33$ $\mathrm{mmol}$ ) and trimethylamine $(1.15 \mathrm{~mL}, 8.33 \mathrm{mmol})$ were dissolved in DCM (15 mL) under inert atmosphere and the reaction mixture was cooled with ice. Afterwards, methanesulfonyl chloride $(0.95 \mathrm{~g}, 8.33 \mathrm{mmol})$ dissolved in dry DCM $(3 \mathrm{~mL})$ was added over 15 minutes and the reaction mixture was stirred at room temperature for 4 hours. The reaction mixture was diluted with DCM $(15 \mathrm{~mL})$, and was washed with cold water $(2 \times 20 \mathrm{~mL})$. Organic phase was dried over sodium sulfate and concentrated under reduced pressure to afford the title 
compound as a viscous oil (yield 96\%). ${ }^{1} \mathrm{H}$ NMR $\left(\mathrm{CDCl}_{3}\right): 4.93$ (bs, $\left.1 \mathrm{H}\right), 4.29(\mathrm{t}, \mathrm{J}=5 \mathrm{~Hz}, 2 \mathrm{H}$ ), $3.48(\mathrm{q}, \mathrm{J}=5 \mathrm{~Hz}, 2 \mathrm{H}), 3.04(\mathrm{~s}, 3 \mathrm{H}), 1.45(\mathrm{~s}, 9 \mathrm{H})$.

Boc-Gly $\Psi\left[\mathrm{CH}_{2} \mathrm{~N}(\mathrm{NBS})\right]$ Gly-OMe 7 (Method A) (15): N-(NBS)-Gly-OMe $(0.19 \mathrm{~g}, 1.43 \mathrm{mmol}$ ), $N$ Boc-ethanolamine $(0.17 \mathrm{~g}, 2.14 \mathrm{mmol})$, and triphenylphosphine $(0.28 \mathrm{~g}, 2.14 \mathrm{mmol})$ were dissolved in dry THF $(15 \mathrm{ml})$ under inert atmosphere. The resulting mixture is cooled to $0{ }^{\circ} \mathrm{C}$ with ice-salt bath and diethyl azodicarboxylate $(0.37 \mathrm{~g}, 2.14 \mathrm{mmol})$ dissolved in dry THF (3 $\mathrm{mL}$ ) was added over 10 minutes in three portions. The reaction was warmed to room temperature, and was further stirred overnight. After the solvent was evaporated in vacuo, oily crude material was re-dissolved in ether and chilled to $0^{\circ} \mathrm{C}$ with ice-salt bath. Precipitated materials were filtered off and crude material was purified with flash column chromatography on silica gel (ethyl acetate/petroleum ether, 1:6-1:3, v:v).

Boc-Gly $\Psi\left[\mathrm{CH}_{2} \mathrm{~N}(\mathrm{NBS})\right]$ Gly-OMe 7 (Method B) (17): To a solution of $N$-(NBS)glycinate methyl ester $(0.5 \mathrm{~g}, 4 \mathrm{mmol})$ in DMF $(15 \mathrm{~mL}), \mathrm{Cs}_{2} \mathrm{CO}_{3}(2.67 \mathrm{~g}, 8.4 \mathrm{mmol})$ was suspended in DMF (15 $\mathrm{mL}$ ) and the reaction was stirred for one hour at room temperature. Then, 2-(Boc-amino) ethyl mesylate $(0.96 \mathrm{~g}, 4 \mathrm{mmol})$ dissolved in DMF $(5 \mathrm{ml})$ was added dropwise for 10 minutes. The reaction mixture was stirred at room temperature for 16 hours. Inorganic salts were filtered and the solvent was evaporated under reduced pressure.

Tert-butyl 2-((ethoxycarbonyl)methylamino)ethylcarbamate 8 (10): To a solution of $N$-(Boc)ethylenediamine $(1.5 \mathrm{~mL}, 9.47 \mathrm{mmol})$ dissolved in a mixture of acetonitrile $(10 \mathrm{~mL})$ and chloroform $(10 \mathrm{~mL}), \mathrm{K}_{2} \mathrm{CO}_{3}(1.35 \mathrm{~g}, 9.84 \mathrm{mmol})$ was added. Ethyl bromoacetate $(1 \mathrm{~mL}, 9.47$ $\mathrm{mmol})$ dissolved in acetonitrile $(10 \mathrm{~mL})$ was added dropwise over six hours under nitrogen atmosphere. After the completion of addition, the reaction mixture was stirred for another 30 minutes. Insoluble materials were filtered off and the solvents were evaporated under reduced pressure. The crude product was purified with flash column chromatography (vide infra) and the title compound is obtained as a yellow liquid (yield 84\%). TLC Rf $(\mathrm{MeOH}) 0.6$ (ninhydrin). ${ }^{1} \mathrm{H}$ NMR $\left(\mathrm{CDCl}_{3}\right): 5.05(\mathrm{~s} \mathrm{br}, 1 \mathrm{H}), 4.20(\mathrm{q}, \mathrm{J}=5,2 \mathrm{H}), 3.42(\mathrm{~s}, 2 \mathrm{H}), 3.22(\mathrm{t}, \mathrm{J}=5.8 \mathrm{~Hz}, 2 \mathrm{H})$, $2.75(t, J=5.8 \mathrm{~Hz}, 2 \mathrm{H}), 1.66(\mathrm{~s}, 1 \mathrm{H}), 1.44(\mathrm{~s}, 9 \mathrm{H}), 1.26(\mathrm{t}, J=5 \mathrm{~Hz}, 3 \mathrm{H})$.

$N$-(N-Boc-2-aminoethyl)-N-[(1-thyminyl)acetyl] glycine ethyl ester 9: The coupling of thymine1 -acetic acid to the intermediate $\mathbf{8}$ was as reported with a minor modification as such neat DMF was utilized as solvent rather than DCM:DMF mixture, as reported by Albrecht et al (18). To a suspension of thymine-1-acetic acid $(2.04 \mathrm{~g}, 11.05 \mathrm{mmol})$ in anhydrous DMF $(20 \mathrm{~mL})$, a solution of HBTU $(5.03 \mathrm{~g}, 13.26 \mathrm{mmol})$ in anhydrous DMF $(20 \mathrm{~mL})$ was added. Then, DIPEA $(2.12 \mathrm{~mL}, 12.16 \mathrm{mmol}$ ) was added to the reaction mixture which is stirred for 1 hour at room temperature. Afterwards, compound $8(2.72 \mathrm{~g}, 11.05 \mathrm{mmol})$ dissolved in DMF $(15 \mathrm{~mL})$ was added and the reaction mixture was further stirred at room temperature overnight. Upon the 
completion of reaction, the solvent was evaporated under reduced pressure. The crude material was dissolved in ethyl acetate $(100 \mathrm{~mL})$ and was washed with saturated solutions of $\mathrm{NH}_{4} \mathrm{Cl}(2 \times 50 \mathrm{~mL}), \mathrm{NaHCO}_{3}(2 \times 50 \mathrm{~mL}), \mathrm{NaCl}(2 \times 50 \mathrm{~mL})$, respectively. The organic phase was dried over $\mathrm{Na}_{2} \mathrm{SO}_{4}$ and concentrated under reduced pressure. The title compound was obtained as a yellow oil (yield 95\%) and was used in the next step without any purification. $R_{f}$ (EtOAc/MeOH, 1:9, v:v) 0.37 (UV).

$\mathrm{N}$-(N-Boc-2-aminoethyl)-N-[(1-thyminyl)acetyl] glycine 10: The intermediate 10 was prepared according to conventional procedures, as exemplified in reference 19 . To a solution of compound 9 (1.90 g, $4.61 \mathrm{mmol})$ dissolved in THF $(50 \mathrm{~mL}), 2 \mathrm{M} \mathrm{LiOH}(50 \mathrm{~mL})$ solution was added dropwise over 15 minutes. The reaction was stirred at room temperature until complete conversion of starting material. Afterwards, the work-up procedures that were utilized independently are as tabulated:

Work-up method A (19): The reaction mixture was extracted with ethyl acetate $(2 \times 25 \mathrm{~mL})$ and remaining aqueous phase is acidified with $1 \mathrm{M} \mathrm{HCl}$ to $\mathrm{pH}=4$ at $0{ }^{\circ} \mathrm{C}$. Aqueous phase was extracted with ethyl acetate $(2 \times 25 \mathrm{~mL})$. Combined organic phases were dried over $\mathrm{Na}_{2} \mathrm{SO}_{4}$ and were concentrated under reduced pressure to afford an oily material (yield 93\%).

Work-up method B (20): The reaction mixture was acidified with $1 \mathrm{M} \mathrm{HCl}$ to $\mathrm{pH}=4$ at $0{ }^{\circ} \mathrm{C}$, and the product was extracted with excess amount of ethyl acetate. Combined organic phases were dried over $\mathrm{Na}_{2} \mathrm{SO}_{4}$ and the solvent was removed under reduced pressure to afford an oily material (yield 45\%). In both cases, ${ }^{1} \mathrm{H}$ NMR analysis of the product revealed that the final compound was pure enough to be used in the subsequent step. TLC $\mathrm{R}_{f}(\mathrm{EtOAC} / \mathrm{MeOH}, 1: 9, \mathrm{v}: \mathrm{v}$ ) 0.61 (UV). ${ }^{1} \mathrm{H}$ NMR (DMSO-d $): 12.54$ (s br, $\left.1 \mathrm{H}\right), 11.30(\mathrm{~s}, 1 \mathrm{H}, \mathrm{mj}), 11.28(\mathrm{~s}, 1 \mathrm{H}, \mathrm{mi}), 7.31$ (s, $1 \mathrm{H}, \mathrm{mj}), 7.27(\mathrm{~s}, 1 \mathrm{H}, \mathrm{mi}), 6.94(\mathrm{t}, 1 \mathrm{H}, \mathrm{mj}), 6.75(\mathrm{t}, 1 \mathrm{H}, \mathrm{mi}), 4.64(\mathrm{~s}, 2 \mathrm{H}, \mathrm{mj}), 4.47(\mathrm{~s}, 2 \mathrm{H}$, $\mathrm{mi}), 4.19(\mathrm{~s}, 2 \mathrm{H}, \mathrm{mj}), 3.97(\mathrm{~s}, 2 \mathrm{H}, \mathrm{mj}), 3.60(\mathrm{~m}, 2 \mathrm{H}, \mathrm{mi}), 1.38(\mathrm{~s}, 9 \mathrm{H})$.

$N$-[2-(Aminoethyl])- $N$-(thymin-1-ylacetyl)] glycine 11 (21): Compound 10 (625 mg, 1.51 $\mathrm{mmol}$ ) was dissolved in $17.9 \mathrm{~mL}$ of TFA/DCM/TIPS (47:50:3). The reaction was stirred at room temperature until TLC indicates complete conversion of compound $\mathbf{1 0}$ and then, volatile materials were evaporated under reduced pressure. The title compound was precipitated from cold ether and was used in the following step as it is, with no characterization, and further purification. TLC Rf $(\mathrm{MeOH}) 0.14$ (UV).

N-Fmoc-PNA-T-OH 12 (22): To a solution of compound $\mathbf{1 1}(2.2 \mathrm{~g}, 7.99 \mathrm{mmol})$ dissolved in THF (40 mL), DIPEA (3.06 mL, $17.5 \mathrm{mmol}$ ) was added. Fmoc-OSu (2.69 g, $8.69 \mathrm{mmol})$ dissolved in dry DMF ( $9 \mathrm{~mL}$ ) was added to the reaction mixture and the flask was sonicated for about five minutes. Reaction mixture was stirred at room temperature until TLC (ethyl 
acetate/hexanes, 1:4) analysis indicated complete conversion of starting material. Afterwards, volatile materials were evaporated under reduced pressure. The crude material is re-dissolved in ethyl acetate $(270 \mathrm{~mL})$ and washed with $\mathrm{KHSO}_{4}(1 \times 90 \mathrm{~mL})$, water $(3 \times 90 \mathrm{~mL})$, respectively. The organic phase was dried over $\mathrm{MgSO}_{4}$ and the solvent is concentrated under reduced pressure. Two procedures were employed independently to optimize the purification of the title compound.

Purification method A: Crude material was simply washed with hexanes to remove trace amount of unreacted Fmoc-OSu and the title compound was obtained as white foam (yield $91 \%)$.

Purification method B: Crude material was purified with flash column chromatography with ethyl acetate/methanol/acetic acid (95:3:2). Combined fractions were poured into chilled water and N-Fmoc-PNA-T-OH was collected by filtration. TLC Rf (EtOAc/Hexane, 1:4) 0.81, 0.94 UV (two structural isomers are observed upon this reaction) (yield 71\%). ${ }^{1} \mathrm{H}$ NMR (DMSO$\left.\mathrm{d}_{6}\right): 12.72(\mathrm{~s}, \mathrm{br}, 1 \mathrm{H}), 11.33(\mathrm{~s}, 1 \mathrm{H}, \mathrm{mj}), 11.31(\mathrm{~s}, 1 \mathrm{H}, \mathrm{mi}), 7.86(\mathrm{~d}, \mathrm{~J}=7.5 \mathrm{~Hz}, 2 \mathrm{H}), 7.69$ (d, $J=7.2 \mathrm{~Hz}, 2 \mathrm{H}), 7.42(\mathrm{~m}, 3 \mathrm{H}), 7.34(\mathrm{~m}, 3 \mathrm{H}), 4.65(\mathrm{~s}, 2 \mathrm{H}, \mathrm{mj}), 4.47(\mathrm{~s}, 2 \mathrm{H}, \mathrm{mi}), 4.37-4.18(\mathrm{~m}$, $4 \mathrm{H}), 3.98(\mathrm{~s}, 2 \mathrm{H}, \mathrm{mj}), 3.26(\mathrm{~m}, 1 \mathrm{H}), 3.10(\mathrm{~m}, 1 \mathrm{H}), 1.73(\mathrm{~s}, 3 \mathrm{H})$.

\section{RESULTS AND DISCUSSION}

As precedented heavily by Berg (23), and Buchardt (24), early reports on synthesis of PNA monomers, as well its oligomers, centred primarily on Boc-chemistry. With Fmoc-chemistry being the current method of choice, numerous research groups endeavored latter on to prepare Fmoc-protected PNA monomers. Assuredly, obviation of hydrogen fluoride synthesis renders the latter prominent for one thing, but more importantly, Fmoc-chemistry is recognized to offer better coupling yields, improved solubility in reaction milieu (25). Yet, this chemistry may be challenging, especially through the synthesis of PNA monomers only because some Fmoc-protected intermediates do not always exhibit comparable reactivity to their Boc-protected counterparts (for a short comparison on this matter, see reference 26). One further drawback regarding this protecting group is the sensitivity of Fmoc moiety to reducing agents (such as $\mathrm{LiAlH}_{4}$ ) or basic reagents (such as $\mathrm{LiOH}$ or $\mathrm{NaOH}$ ). Thus, it appears that a plausible approach to access both $N$-Boc-PNA-T-OH and $N$-Fmoc-PNA-T-OH is to synthesize the former at first, whereupon it is converted to $\mathrm{N}$-Fmoc-PNA-T-OH.

With this paradigm, we initially sought to prepare Boc-protected backbone of PNA through Mitsunobu reaction because of its prevalence in the synthesis of PNA chemistry (see pathway B in Scheme 2) (27). Although mostly favoured in the attachment of nucleobases to the backbone (28), Mitsunobu reaction is also conformed to the synthesis of PNA backbone (15). 
In keeping with the report by Wiśniewski, this synthetic route commences with esterification of glycine amino acid via methanolic solution of $\mathrm{SOCl}_{2}$ (Scheme 3). Subsequently, methyl glycinate hydrochloride $\mathbf{4}$ is converted to methyl $N$-(NBS)-glycinate $\mathbf{5}$ in good yield. However, we came to notice that we genuinely failed to reproduce Mitsunobu reaction between $\mathbf{4}$ and $\mathbf{5}$ to afford Boc-Gly $\Psi\left[\mathrm{CH}_{2} \mathrm{~N}(\mathrm{NBS})\right] \mathrm{Gly}-\mathrm{OMe} 7$ backbone. This finding is supported by ${ }^{13} \mathrm{C}$ NMR of the isolated product that reveals the lack of ethylene bridge on the backbone that should have appeared in the region between $40 \mathrm{ppm}$ and $50 \mathrm{ppm}$. With methyl $N$-(NBS)-glycinate in our hand, we next explored the synthesis of $\mathbf{7}$ through conventional alkylation of $\mathbf{5}$. In that regard, methyl $\mathrm{N}$-(NBS)-glycinate reacted with 2-(Boc-amino) ethyl mesylate 6 under basic condition. Unlike Mitsunobu reaction, this reaction afforded the peptidic backbone in moderate yield based on TLC. However, $r_{f}$ of $\mathbf{7}$ being similar to that of $\mathrm{N}$-(NBS)-glycinate rendered the chromatographic purification rather time-consuming.

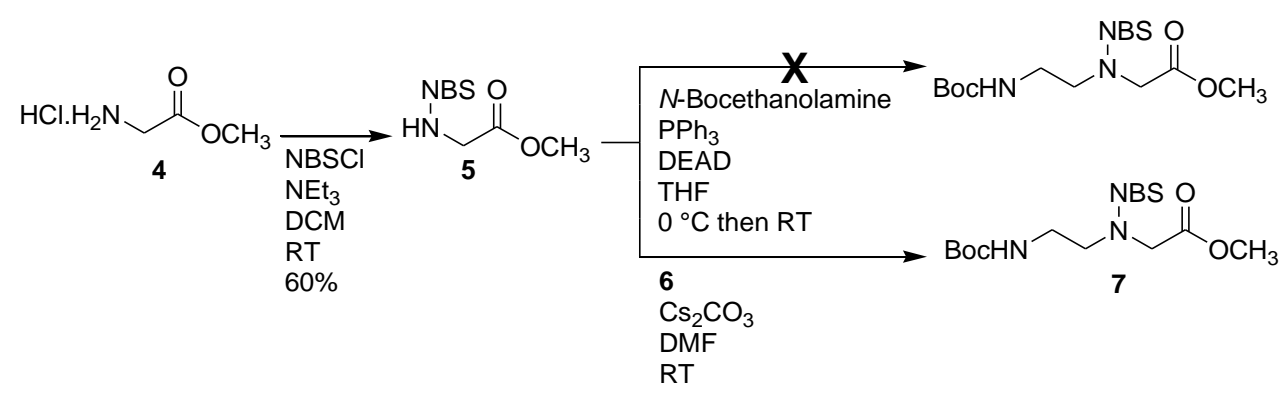

Scheme 3. The synthesis of PNA backbone through N-(NBS)-Gly-OMe intermediate (pathways $B$ and $C$ of Scheme 2).

In light of these results, we turned our attention to synthetic pathways D and E (vide supra), wherein the positions of nucleophile and electrophile are switched. With the latter being reported to be irreproducible, synthetic pathway $\mathrm{D}$, wherein $N$-Boc-ethylenediamine reacts with methyl bromoacetate, was investigated to synthesize PNA backbone 3 (Scheme 4) (10). In contrast to previously depicted ones, the synthetic route was free-of-trouble and proceeded very smoothly. As reported by many groups, the sole problem we have also encountered was unmanageable di-alkylation of $\mathrm{N}$-Boc-ethylenediamine, which necessitated one further step of purification. Taking the basic character of product into consideration, we firstly attempted to isolate intermediate $\mathbf{8}$ (Scheme 4) through neutral alumina, in lieu of conventional silica gel (ethyl acetate/hexanes, $1: 2, \mathrm{v}: \mathrm{v}$ ). Nonetheless, we have managed to isolate only $43 \%$ of crude material, presumably because the title compound tended to stick even to neutral alumina. Oddly enough, the use of basic alumina did not alter this profile either, which ultimately compelled us to opt for more aggressive solvent systems. With a solvent of system of $\mathrm{DCM} /$ methanol/ $\mathrm{NH}_{4} \mathrm{OH}(95: 5: 0.8, \mathrm{v}: \mathrm{v})$, and silica gel, the isolated yield eventually neared to $84 \%$, which was very much in concert with the relevant literature (10). In short, it is safe to conclude that the intermediate $\mathbf{8}$ could be prepared the most conveniently from $\mathrm{N}$-Boc- 
ethylenediamine, and ethyl bromoacetate in high yield, and purity, based on our personal experience.
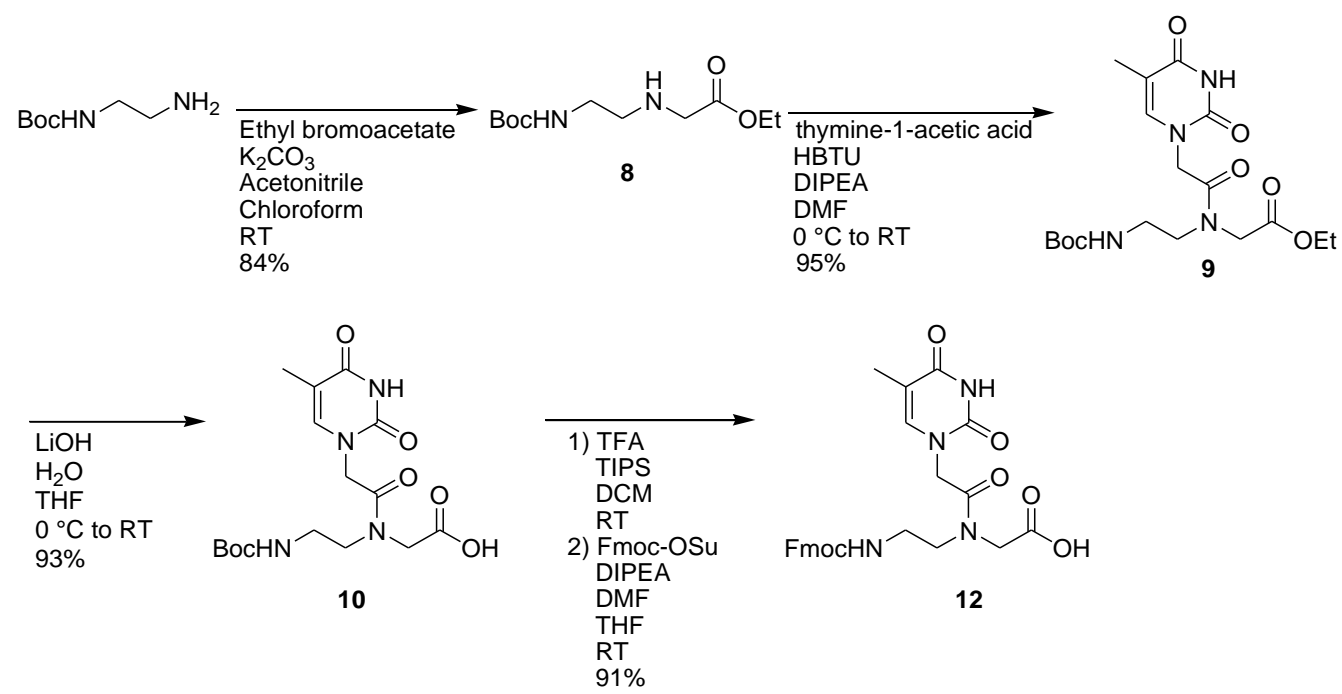

Scheme 4. The sequential synthesis of $N$-Boc-PNA-T-OH, and $N$-Fmoc-PNA-T-OH from $N$-(Boc)-ethylenediamine.

The coupling of thymine-1-acetic acid to $\mathbf{8}$ are conventionally achieved with reagents such as $N, N^{\prime}$-dicyclohexylcarbodiimide (DCC) coupled with 3-hydroxy-1,2,3-benzotriazin-4-one (DhbtOH) (28) or HBTU (29). Not only these reactions reportedly afforded 9 in moderate-togood yield, but also the latter reportedly obligated a purification step, which accounts for a slight disadvantage. In respect to this complication, we recognized that the reaction could only be improved by altering the order in the addition of compounds. Rather than reacting $\mathbf{8}$, thymine-1-acetic acid, and HBTU at once - as stated in references 28, and 29, we preactivated thymine-1-acetic acid with HBTU for one hour at first, and then added the backbone $\mathbf{8}$ to the reaction mixture. In this manner, we obtained the title compound in $95 \%$ yield, and in sufficient purity after overnight reaction, and standard work-up procedure detailed in experimental part (vide supra).

Surprisingly, the perplexing part of this synthetic route was de-esterification of 9, as we have experienced that work-up procedure drastically impacted the yield. Therein, work-up procedure following the reaction involved acidification with $1 \mathrm{M} \mathrm{HCl}$, followed by the extraction of title compound with ethyl acetate (20). However, we have observed that with this procedure, the yield was no more than $45 \%$, and more interestingly, a UV-active by-product was formed in aqueous phase, while acidification. At this point, our failure to retrieve this byproduct with extraction led us speculate that the process of acidification may have essentially conduced towards a side-reaction whereupon a highly polar compound is formed. On the contrary, we found out that washing the reaction with ethyl acetate prior to acidification raised the yield to $90 \%$, with no sign of this by-product (19). Considering well-documented stability of Boc group and PNA monomer under slightly acidic conditions, what might have triggered 
this side-reaction remained predominantly vague to this point. On the verge of these observations, we should remark that work-up procedure by Tsantrizos appear to be the most suited one to achieve high yield in this step.

The procedures to cleave Boc moiety, and subsequently to introduce Fmoc group were in compliance with references 21 , and 22, respectively. Boc group was removed from 10 with TFA/DCM/TIPS (47:50:3), and Fmoc group was subsequently introduced through Fmoc-OSu in the presence of DIPEA. In these two steps, the sole complication we faced was the purification of final compound $\mathrm{N}$-Fmoc-PNA-T-OH. In this context, we have initially attempted to purify the crude material via flash column chromatography with ethyl acetate/methanol/acetic acid (95:3:2). However, inability to remove solvents afterwards coerced us to pour combined organic fractions on ice and water, and to obtain 12 through filtration. Because this approach, however, caused loss of material to some extent, we considered simply to wash the crude material with hexanes, instead. Frequently utilized after reaction involving Fmoc-OSu, this method indeed removed impurities without any substantial loss of product, and is seemingly applicable to the synthesis of $N$-Fmoc-PNA-T-OH, as well.

\section{CONCLUSION}

As outlined in Scheme 2, N-Boc-PNA-T-OH, and N-Fmoc-PNA-T-OH could be synthesized through many synthetic routes and methodologies. Despite all the efforts in this field, we came to realize that certain reaction and synthetic routes still need some improvements, and modifications, which encouraged us to conduct this study. Of them, we have experienced that the best approach to attain these two monomers is through $\mathrm{N}$-Boc-ethylenediamine, where yields of reactions are ca. $90 \%$, in addition to each reaction being fully reproducible.

\section{ACKNOWLEDGMENT}

This research was supported by Research Fund of Istanbul Technical University (Project Number: 38056 and 38866).

\section{REFERENCES}

1. Nielsen PE, Egholm M, Berg RH, Buchardt O. Sequence-selective recognition of DNA by strand displacement with a thymine-substituted polyamide. Science $1991 ; 254: 1497-1500$.

2. Jensen KK, Örum $H$, Nielsen PE, Nordén B. Kinetics for hybridization of peptide nucleic acids (PNA) with DNA and RNA studied with the BIAcore technique. Biochemistry 1997; 36(16):5072-5077.

3. Ray A, Nordén B. Peptide nucleic acid (PNA): its medical and biotechnical applications and promise for the future. FASEB J. 2000; 14(9):1041-1060.

4. Brandt O, Feldner J, Stephan A, Schröder M, Schnölzer M, Arlinghaus HF, Hoheisel JD, Jacob A. PNA microarrays for hybridization of unlabelled DNA samples. Nucleic Acids Res. 2003; 31(19):e119. 
5. Tian K, He Z, Wang Y, Chen S-J, Gu L-Q. Designing a Polycationic Probe for Simultaneous Enrichment and Detection of MicroRNAs in a Nanopore. ACS Nano 2013; 7(5):3962-3969.

6. Stender H, Williams B, Coull J. PNA fluorescent in situ hybridization (FISH) for rapid microbiology and cytogenic analysis. Methods Mol. Biol. 2014; 1050:167-178.

7. Manna A, Rapireddy S, Sureshkumar G, Ly DH. Synthesis of optically pure yPNA monomers: a comparative study. Tetrahedron 2015; 71(21):3507-3514.

8. Falkiewicz B, Kozyra A, Kolodziejczyk AS, Liberek B, Wisniewski K. New procedure of the Mitsunobu reaction as the key step in peptide nucleic acid (PNA) monomers synthesis. Nucleic Acids Symp. Ser. 1999; 42:9-10.

9. Bonnard V, Azoulay S, Di Giorgio A, Patino N. "Polyamide Amino Acids": a new class of RNA Ligands. Chem. Commun. 2009; 17:2302-2304.

10. Aldrian-Herrada G, Rabié A, Wintersteiger R, Brudiou J. Solid-phase synthesis of peptide nucleic acid (PNA) monomers and their oligomerization using disulphide anchoring linkers. J. Pept. Sci. 1998; 4(4):266-281.

11. Feagin TA, Shah NI, Heemstra JM. Convenient and Scalable Synthesis of Fmoc-Protected Peptide Nucleic Acid Backbone. J. Nucleic Acids 2012; 354549.

12. Debaene F, Da Silva JA, Pianowski Z, Duran FJ, Winssinger N. Expanding the scope of PNA-encoded libraries: divergent synthesis of libraries targeting cysteine, serine and metalloproteases as well as tyrosine phosphatases. Tetrahedron 2007; 63(28):6577-6586.

13. Altenbrunn F, Seitz O. O-Allyl protection in the Fmoc based synthesis of difficult PNA. Org. Biomol. Chem. 2008; 6(14):2493-2498.

14. Coban G, Kose FA, Kirmizibayrak PB, Pabuccuoglu V. Synthesis, biological activity screening and molecular modeling study of acylaminoacetamide derivatives. Med. Chem. Res. 2015; 24(10):3710-3729.

15. Falkiewicz B, Kolodziejczyk AS, Liberek B, Wiśniewski K. Synthesis of achiral and chiral peptide nucleic acid (PNA) monomer using Mitsunobu reaction. Tetrahedron, 2001; 57(37):7909-7917.

16. Fox BM, Beck HP, Roveto PM, Kayser F, Cheng Q, Dou H, Williamson T, Treanor J, Liu H, Jin L, Xu G, Ma J, Wang S, Olson SH. A Selective Prostaglandin $E_{2}$ Receptor Subtype 2 (EP2) Antagonist Increases the Macrophage-Mediated Clearance of Amyloid-Beta Plaques. J. Med. Chem. 2015; 58(13):5256-5273.

17. Patino N, Di Giorgio C, Dan-Covalciuc C, Peytou V, Terreux R, Cabrol-Bass D, Bailly C, Condom R. Modelling, synthesis and biological evaluation of an ethidium-arginine conjugate linked to a ribonuclease mimic directed against TAR RNA of HIV-1. Eur. J. Med. Chem. 2002; 37:573-584.

18. Albrecht M, Zauner J, Eisele T, Weis P. The Synthesis of Catechol and 8-Hydroxyquinoline Derivatives with Short Peptide-Type Side Chains: Metal Complex Ligands with Additional Receptor Properties. Synthesis 2003; 7:1105-1111.

19. Fader LD, Boyd M, Tsantrizos YS. Backbone Modifications of Aromatic Peptide Nucleic Acid (APNA) Monomers and Their Hybridization Properties with DNA and RNA. J. Org. Chem. 2001; 66(10):33723379.

20. Sahu B, Sacui I, Rapireddy S, Zanotti KJ, Bahal R, Armitage BA, Ly DH. Synthesis and Characterization of Conformationally Preorganized, (R)-Diethylene Glycol-Containing Y-Peptide Nucleic Acids with Superior Hybridization Properties and Water Solubility. J. Org. Chem. 2011; 76(14):56145627.

21. Pensato S, Saviano M, Bianchi N, Borgatti M, Fabbri E. c-Hydroxymethyl PNAs: Synthesis, interaction with DNA and inhibition of protein/DNA interactions. Bioorg. Chem. 2010; 38(5):196-201.

22. Slaitas A, Yeheskiely E. A Novel N-(Pyrrolidinyl-2-methyl) glycine-Based PNA with a Strong Preference for RNA over DNA. Eur. J. Org. Chem. 2002; 14:2391-2399.

23. Egholm M, Buchardt O, Nielsen PE, Berg RH. Peptide Nucleic Acids (PNA) Oligonucleotide Analogues with an Achiral Peptide Backbone. J. Am. Chem. Soc. 1992; 114(5):1895-1897. 
24. Dueholm KL, Egholm M, Behrens C, Christensen L, Hansen HF, Vulpius T, Petersen KH, Berg RH, Nielsen PE, Buchardt O. Synthesis of Peptide Nucleic Acid Monomers Containing the Four Natural Nucleobases: Thymine, Cytosine, Adenine, and Guanine and Their Oligomerization. J. Org. Chem. 1994; 59(19): 5767-5773.

25. Thomson SA, Josey JA, Cadilla R, Gaul MD, Hassman CF, Luzzio MJ, Pipe AJ, Reed KL, Ricca DJ, Wiethe RW, Noble SA. Fmoc mediated synthesis of Peptide Nucleic Acids. Tetrahedron 1995; 51(22):6179-6194.

26. Feagin TA, Shah NI, Heemstra JM. Convenient and Scalable Synthesis of Fmoc-Protected Peptide Nucleic Acid Backbone. J. Nucleic Acids 2012; 354549.

27. Wisniewski K, Joswig S, Falkiewicz B, Kolodziejczyk A. A New Method of the Synthesis of Gly-Aaa Type Reduced Peptide Bond. Pol. J. Chem. 1997; 71(10):1506-1509.

28. For instance, see: Li $P$, Zhan C, Zhang S, Ding X, Guo F, He S, Yao J. Alkali metal cations control over nucleophilic substitutions on aromatic fused pyrimidine-2,4-[1H,3H]-diones: towards new PNA monomers. Tetrahedron 2012; 68(43):8908-8915.

29. For instance, see: Ellipilli, S.; Palvai, S.; Ganesh, K. N. Fluorinated Peptide Nucleic Acids with Fluoroacetyl Side Chain Bearing 5-(F/CF3)-Uracil: Synthesis and Cell Uptake Studies. J. Org. Chem. $2016 ; 81: 6364-6373$. 